\title{
11
}

\section{Legal Aid and Clinical Legal Education in Europe and the USA: Are They Compatible?}

\author{
Richard J. Wilson
}

\section{Introduction}

Clinical legal education has made enormous global advances in the past few decades, primarily as a means of providing students with supervised experience in the practice of law as a formal part of the law school curriculum. Nowhere has this phenomenon grown more rapidly, and in some ways, more surprisingly, than in Western Europe. Europe combines a tradition of the magisterial lecture, a method for which partisans have advocated since the Middle Ages, with a period of practical training after law school, designed to accomplish many of the goals of a clinical experience in school. European professors are not generally practitioners of law. Yet the phenomenon grows apace everywhere, Europe being no exception.

This chapter will examine the growth of clinical legal education in one particular historical context in Europe and the USA: that of clinics

\footnotetext{
R.J. Wilson ( $\square)$

Washington College of Law, American University, Washington, DC, USA

(C) The Author(s) 2018

O. Halvorsen Rønning, O. Hammerslev (eds.), Outsourcing Legal Aid

in the Nordic Welfare States, https://doi.org/10.1007/978-3-319-46684-2_11
} 
providing systematic legal aid services in civil matters to those who cannot afford counsel. It will begin with some basic definitional issues regarding what is 'clinical' in the US legal academy, as well as some basic parameters of the legal aid paradigm. The second part of the chapter will compare and contrast the historical development of clinics in the USA with those in Central and Western Europe. The US experience will give particular focus to the decade of the 1980s, during the presidency of Ronald Reagan, a crisis period for civil legal aid on a national scale, while clinical legal education was growing dramatically as an alternative pedagogy within law schools. The European experience will give particular attention to events in Central Europe after the fall of the Soviet Union, with a focus on Poland as one jurisdiction that provides legal aid through clinics. A more recent look at clinics shows a shift in both more recent experience in US law schools, and a diversity of models for clinical work in newer programmes in Western Europe. Several examples will be noted in a final section. Having provided that basis for comparison, the chapter will conclude by asking the none-too-rhetorical question of whether law school clinics should be a major provider of legal aid in any national scheme. At this stage in the European experience, it is defensible to argue the 'let a hundred flowers bloom' theory of clinical education, as experimentation and academic, local, or national conditions may dictate particular models for particular times.

\section{Definitions: Clinical Legal Education and Legal Aid}

\section{Clinical Education}

Some suggest that clinical legal education is part of a range of experiential learning methods that can be utilised in the law school curriculum, including them among such models as externships, which provide an out-placement of students in a law office, usually with an accompanying seminar for credit in the law school, or simulation-based courses that provide students with fact-based legal problem solving situations (Milstein 2001). In the context of this chapter, I use a somewhat more 
specific definition of clinical legal education, though without some elements that I have emphasised elsewhere. The most relevant elements in this context are three: (1) the provision of legal advice or services to actual clients, whether in court or not, by law students; (2) clients of the clinic are persons without the resources to retain counsel, or persons or groups in underserved or marginal communities; and (3) all student work is reviewed closely by, regularly supervised by, and may be vouched for by, a member of the bar, hopefully a member of the faculty of the school where the clinic is located. An ideal clinical experience has two additional elements, some of which require time and effort within the law school: (4) the participation of law students is given academic credit within the institution in which the student is enrolled and is an integrated part of the course of study in law school; and (5) the student is prepared for interactions with clients by either a preparatory or a parallel course of study that focuses on the doctrine, skills, ethics, and values of professional practice in the law. The most robust and effective clinics combine all five elements (Bryant et al. 2014).

\section{Legal Aid and 'Legal Services'}

Legal aid, as a term of art, means different things in the historical and constitutional context of the USA than it does in most other parts of the world. Legal aid in the USA generically refers to the provision of legal services for indigent persons who cannot afford to retain counsel, but its scope and structures are radically different from continental Europe in practice, distinguishing sharply between services provided in criminal versus civil cases.

In the criminal law context, the origins of defence of the indigent poor (who are the overwhelming majority of all persons charged with any crime anywhere) primarily lie with the US Supreme Court's 1963 decision in Gideon v. Wainwright, holding that an indigent person charged with a felony offence in state court, where the overwhelming number of criminal prosecutions occur, is entitled, under the Sixth Amendment to the US Constitution, to counsel at state expense (Gideon 1963). Gideon and related cases before and after it, at both the federal and state levels, 
have mandated systemic structures to provide access to a lawyer, both at trial and on appeal, for all of those indigent criminal accused sent to jail. The three major systems used today in the USA for legal aid in criminal matters include staffed public defender offices, contracts for services by law firms, and lists of individual counsel assigned by trial court judges. All are compensated by the state, but may be paid by federal, state, or local budgets (Mounts and Wilson 1986, p. 197). The constitutional right to counsel does not extend to discretionary appeals or prisoners under sentence.

Legal aid in all other contexts - civil, administrative, immigration, etc. - is through funds appropriated by the national, state, and local legislatures or raised by legal aid programs to meet their budgetary needs. There is no federal constitutional right to counsel in US civil cases. Funding for civil legal aid programmes comes largely from federal or state appropriations of funds by statute or court rule. The biggest single programme in the USA is the federal Legal Services Corporation (LSC), founded in 1974 during the administration of Richard Nixon. Although state and local funding is now almost double that of LSC's budget, the LSC remains the largest single provider of civil and related legal services for the poor. In addition to guidelines limiting representation to those with poverty-level incomes, the LSC is burdened by dozens of restrictions limiting access to certain populations such as immigrants, and limitations on certain client groups, such as undocumented immigrants, and certain types of advocacy, such as legislative lobbying and class actions (Houseman and Perle 2013, pp. 34-40). As used throughout this chapter, the term 'legal services', taken from the name of the principal entity funding such services, refers to civil legal aid matters only, not to legal aid in criminal matters.

As is discussed throughout this volume, legal aid schemes in Europe generally, and the Nordic region specifically, are mostly state-administered programmes with budgets to provide legal services to the poor in both criminal and civil legal matters, often without income or asset limits on clients to be served. In recent years in Europe, insurance for legal issues can defray costs of legal aid for many, while legal insurance is virtually unknown in the USA. In the context of this chapter, I am discussing only civil legal aid in the USA, while referring comprehensively to all legal aid in Europe. 


\section{Legal Aid and Clinics in the USA: The Reagan Assault on Legal Services}

\section{The Earliest US Clinics: Europe's Surprising Role}

The early history of clinical legal education in the USA is deeply and inextricably linked to the provision of legal aid for the poor. Scholars have noted what they call the 'legal aid origins' of clinical legal education, not only in the USA but in many other countries as well, including Australia, India, and South Africa (Bloch and Noone 2011, p. 153). Within the USA, they mention the establishment, in the 1920s, of student-directed 'legal aid societies', often voluntary, at the law schools at Yale, the University of Southern California, and the University of Chicago. These programmes were established, first and foremost, to provide legal services to those who would not otherwise have access to a lawyer or the courts (Ibid., p. 157). While these efforts are noteworthy, my own research has discovered roots much earlier, in the late nineteenth century, and with a surprising connection to Europe.

Arthur von Briesen, a private lawyer who led the early legal aid movement in New York City, became the first President of the New York Legal Aid Society. The Society, founded in 1876, is the oldest and largest notfor-profit legal aid programme in the USA. Even in its earliest days, it sought ways to expand the scope of its services. Von Briesen, who assumed leadership in 1890 of what had been largely a programme serving the German immigrant community in New York City, travelled abroad on a study tour. He returned with news of a grand experiment in Copenhagen, Denmark. There he found a programme called Studentersamfundets Retshjelp for Ubemidlede, translated as 'The Student Association for Securing Legal Aid for the Poor', but known popularly as the Legal Aid Society (von Briesen 1907). Another early legal aid activist lawyer, Reginald Heber Smith, in his own contemporary work, supplements the observations of von Briesen, noting that the Copenhagen Society was founded by the University of Copenhagen in 1885 (Smith 1919, p. 227). Von Briesen writes that the Society received national, city, and university financial support for its operations. The programme was simple and 
direct in providing legal services to the needy. It was housed in a building with seven rooms. Each night of the week, except Sundays, seven different prominent lawyers and judges, all graduates of the university, sat in the rooms, doing intakes on cases. These 42 lawyers were joined by one law student per room per night, assigned from the University of Copenhagen law faculty, a total of 42 law students every semester. One paid staff lawyer, together with a paid clerk, completed whatever work needed to be done if a case could not be resolved in the first encounter. Students assisted with interviewing and research, with some drafting. Any case that went to court was done by a practising lawyer, often with the student seated at his side. During the year 1906, according to von Briesen, the programme did an extraordinary 25,782 intakes, resulting in some 7000 files being opened. Of the opened files, 114 cases were settled and 88 brought to trial, and 61 trials achieved results favourable to Society clients. Von Briesen comments that the confidence of clients in these lawyers and students is naturally very great; their decisions are taken without a murmur and terminate what otherwise might become much needless controversy.' (von Briesen 1907, p. 26) To my knowledge, this is the first known programme of clinical instruction in the world, and its roots are in Europe, not the USA.

Von Briesen was interested in the structure of the Society, primarily, because of its ability to extend the scope of legal services to the poor, so he documented neither the origins of the programme nor whether it provided students with credit for their participation, but he did suggest pedagogical value through the law students' 'actual contact with litigants and their skilled advisers', as well as 'a great variety of questions, some of considerable intricacy, the solution of which will be of more value to the students even than to the party who deems himself aggrieved.' (Ibid., pp. 26-27).

The Copenhagen model, and other domestic proposals, gained some attention in the USA, and led to what might be called the earliest of clinical models in the USA, denominated generally as the 'legal aid clinic' and taking its name from medical practice in a clinical setting (Bradway 1933). In an era in which there was no national programme of legal aid services, some called for clinics in law schools to take on a significant role in providing assistance in legal aid cases as a means to train law students for practice. The impulse behind these efforts was a noble one focused on 
the professional training of law students for practice: as Smith notes in his early work, there is 'a gap in the present method of training lawyers. The law schools do not teach practice. The law offices do not teach practice. The student is left to pick up his information about the conduct and procedure of cases in any way and in any place that he can manage to find it.' (Smith 1919, p. 230).

John Bradway, who ran the Duke University Legal Aid Clinic in Durham, North Carolina for 28 years, from 1931 to 1959, was an eager proselytiser for legal aid clinics. In the dozens of articles he wrote on legal aid clinics for law schools and the popular press, including the one cited here, he never raised any concern about excessive case- or workloads for students in clinics. His concern for clients and the integrity of their cases was expressed instead in his insistence that students be adequately and closely supervised by a practicing lawyer. Writing in 1936, Bradway and the prominent lawyer Reginald Heber Smith documented the growth of legal aid work in the USA from its origins (Smith and Bradway 1936). They offer a full chapter on the earliest relationships between law schools and legal aid, documenting the work of legal aid clinics in law schools between 1893 and 1916. Their introductory overview of the work is instructive:

'The legal aid clinic is the outgrowth of certain needs common to the legalaid movement and to legal education. Each group exploring the boundaries of its own field found in the interstitial area possibilities for mutual development.' (Ibid., p. 156)

Certainly this was true then. The remainder of this chapter explores more recent history, when the social and pedagogical missions of clinics become more contested, and one mission might prevail at the cost of the other.

\section{The Second Wave: Social Activism in the 60s and Beyond}

Later writings on the topic document the now-conventional story that the US clinical movement finds its greatest period of dynamism and expansion in the social movements of the turbulent 1960s and 1970s. Barry and co-authors appropriately call this phase the 'second wave' of 
clinical legal education, following the first wave in the early twentieth century, discussed above (Barry et al. 2000, p. 12). The second wave covers the period from the 1960s up to the late 1990s. According to the authors, new clinics during this period were designed almost exclusively to respond to a demand by law students for relevance in their training, as well as a desire to use the law as an instrument of social change, primarily through the provision of legal services to the poor, who would otherwise not have access to the legal system or justice itself (Ibid., pp. 12-14). The authors note that new clinics during that time also served deeper social goals. Clinical courses 'expose students not only to lawyering skills but also the essential values of the legal profession: provision of competent representation; promotion of justice, fairness, and morality; continuing improvement of the profession; and professional self-development.' (Ibid., p. 13).

\section{Crisis: Reagan's Attacks on Legal Services via Clinics}

Although the social justice motif was strong in early clinics, few US clinics aspired to seriously fill the yawning need for more legal aid in civil matters. Instead of high-profile 'impact litigation' or massive numbers of cases, clinics during this period leaned towards the use of simulation to introduce lawyering skills and the small-case model, with low numbers of clients and slowly unfolding litigation that provided students with many opportunities for reflection and change in case theory or direction as cases developed over time before an actual court hearing (Schrag and Meltsner 1998, p. 18, 40). Clinics received a boost in support through Ford Foundation grants that allowed virtually any law school that wanted a clinic to have one, so long as the school was willing to match foundation funding. Ford's Council on Legal Education for Professional Responsibility (CLEPR) programme dispensed over \$11 million during the 1970s, then 'vanished, as planned.' During that time period, more than half of US law schools had received CLEPR funding for their clinical programs. By the end of the 1980s, 98\% of accredited law schools offered clinical legal education of some kind, in no small measure due to the seed-money efforts of the CLEPR movement (Schrag and Meltsner 1998, pp. 5-7). 
The 1960s and 1970s were also a time of enormous development of civil legal services for the poor in the USA. Again, the Ford Foundation funded a small number of legal services offices that became a model for the first federally-funded legal services programme. In 1965, the US Office of Economic Opportunity (OEO) created a Legal Services Programme that grew to over $\$ 70$ million a year, in 1974 , through grants to local non-profit groups of lawyers to provide civil legal services (Rhudy 1994, pp. 231-232). These programmes, largely independent, literally transformed US poverty law practice, with dozens of stunning victories in the US Supreme Court on behalf of poor people throughout the nation. The welfare rights movement, in no small measure, owed its success to these OEO-funding programs (Lawrence 1990; Davis 1995). In fact, many suggest that the early successes of the programme were what led to the right-wing political backlash against legal aid in the following decades. OEO Legal Services was replaced by the national Legal Services Corporation (LSC), established in 1974 during the presidency of the illfated Richard M. Nixon, the only US president to resign the office.

Legal clinics did play a role in legal aid delivery in civil matters. As early as 1978, a report from the federal General Accounting Office on the operations of the recently created LSC indicated that about 30\% of all grantees reporting in their survey used law students 'as a resource.' This included using students as programme paralegals and supplemental staff, not necessarily through clinical programmes, although the same report documents a single law-school-based clinic with a staff of five lawyers who devoted $30 \%$ of their budget to civil legal services, and seven law schools 'with programmes which provide legal services to the poor.' (US General Accounting Office 1978, pp. 10-11)

Ronald Reagan became president of the USA in 1981, having served as governor of California from 1967 to 1975 . He arrived in Washington as a new conservative voice, which included strong negative attitudes about government expenditures on legal aid for the poor. During the time of his governorship, his administration had clashed deeply with California Rural Legal Assistance (CRLA), a state-wide legal aid programme funded as part of the OEO Legal Services Program mentioned above. He lost repeatedly. The CRLA scored a series of court victories on behalf of braceros, temporary Mexican workers imported to assist big 
agribusiness in California. When the press painted Reagan in an embarrassing light, he vowed revenge against the programme and others of its ilk, and took it by repeated attempts, all unsuccessful, to prevent funding from OEO to CRLA (Bennett and Reynoso 1972).

The newly elected President Reagan reignited his antagonism to legal aid immediately after his arrival in Washington in 1981. His first federal budget provided for zero funding for the LSC, which, at the time, was operating with a budget of $\$ 321$ million nationwide. When Congress, and strong supporters, particularly the voluntary, but politically powerful, American Bar Association (ABA), rallied to assure adequate funding for the LSC in the budget, and Reagan didn't have the votes to deny all funding, he shifted his strategy to one of slowly strangling the Corporation through indirection. He named members of the national board of directors who were hostile to the programme. He managed to significantly cut the LSC budget, by a third from 1981 to 1982, resulting in the loss of 1773 lawyers and 2860 other staff in a single year. Many of these lawyers were the most experienced and seasoned veterans of the programme. Three hundred field offices were closed, and 17 national backup centres, which provided essential technical expertise to the field, were threatened with closure (and eventually did close) (Abel 1985, pp. 547-548).

In the spring of 1981, President Reagan's old friend and colleague from the California years, Attorney General Ed Meese, proposed that the legal needs of the poor could be met by law students working in law school clinical programmes. In a commencement speech at the law school of the University of Delaware, Meese suggested an 'expansion' of clinical programmes to establish 'neighbourhood law offices for the poor', working under the supervision of lawyers who would donate time to supervise the work. In a press conference preceding the address, he noted that most legal aid matters were 'relatively simple legal cases - landlord cases, divorce cases, creditor-debtor cases, that sort of thing.' Such matters were the kind of thing staff lawyers had done, he asserted, and the LSC lawyers themselves 'are usually lawyers in their first few years of practice, too, and they don't have as adequate supervision as you would have in the programme I'm going to outline.' (Stuckey 2005, p. 12) Whether straightforward or cynically calculating, the Meese speech and subsequent actions within LSC to fund legal aid programmes in law school clinics were seen 
as part of the Reagan strategy to cut legal aid funding or water down services. A national newsletter circulated to law school clinics by the Association of American Law Schools (AALS) noted, in November of 1983, that the LSC was funding a pilot law school clinic project 'to supplement services offered by existing legal services programmes.' Eight to twelve accredited law schools would be awarded grants between $\$ 50,000$ and $\$ 100,000$ over 18 months. The newly appointed president of the LSC, a corporate lawyer with no prior experience in poverty law, called the grants an opportunity to tap into the 'well-spring of talent and dedication' of law students to work on behalf of the poor (LSC Announces New Clinical Program, Nov. 1983).

Reaction from the clinical teaching community was immediate and almost completely hostile. A short essay in a clinical community newsletter, written by a clinical teacher from the University of Maryland, urged clinics not to apply for the proposed grants (Capowski 1984, pp. 24-25). Capowski gave four reasons not to do so. First, he argued, funding for legal aid should go to 'the most efficient providers of legal services for the poor.' Dollars taken by clinics would result in further cuts to already severely underfunded staff programmes. Second, clinics, by their nature, 'require significant supervision and low student caseloads.' They are inherently 'ineffective in reaching large numbers of clients.' Third, taking grants might create conflicts of interest for clinics seeking to engage in law reform activities, which are inimical to Congressional restrictions imposed on all LSC grantees. Finally, because the current direction of the LSC was toward abolition of the staff model in favour of private bar delivery, any funding of clinics was disingenuous, and would end all too soon.

However, clinics were still experiencing the growth phase of their adolescence, and law schools were often reluctant to fund what was seen as an expensive addition to a law school's curriculum. The LSC funding proposal was tempting to some schools. In June of 1984, the AALS Newsletter announced that nine law schools had received LSC grants between $\$ 65,000$ and $\$ 95,000$, selected from 57 'high-quality grant proposals.' The primary function of the grants, according to the LSC Washington office under control of Reagan appointees, was to 'test' whether clinics can be 'an efficient and effective means of augmenting the 
work of existing legal aid programmes.' Other goals of the programme were said to be to enhance the education of law students and to create a future group of lawyers interested in providing legal services to the poor (LSC Announces Grants, June 1984, pp. 7-8).

The issue continued to churn through the clinical teaching community. One more newsletter entry, in November of 1987, indicates that the LSC made grants totalling over one million dollars for the 1987-1988 academic year. The grants went to 27 law schools and ranged from a low of $\$ 26,615$ to a high of $\$ 50,000$. The newsletter notes the lack of consensus' among members of a Committee on Legal Services of the clinical community, as to whether law schools should, or should not, accept grant funding (Committee on Legal Services Nov. 1987, p. 4). In a 1990 publication from the generally conservative American Enterprise Institute, the LSC's coordinator of the law school clinic grants wrote. His data conform generally with the dates and amounts recorded here, and then he notes that only 'two-tenths of 1 percent of the resources of the corporation have gone into this programme, even though we have a total pool of 176 law schools accredited by the American Bar Association. So we are not dedicating huge resources to the project.' Later in the same presentation, he notes that in the 18 months during which the grant operated with the grantee schools, 5500 cases were completed; while another 2000 were pending. Client surveys of satisfaction were very high, with $81 \%$ satisfied with the outcome and $92 \%$ satisfied with the quality of service. Students in the programme also showed a significantly greater likelihood of providing pro bono services in the future (Moses 1990, p. 169, 171). I found no other evidence that additional funding was provided to clinics from the LSC.

The small percentage of grant funding for clinics, together with active resistance from the clinical community, seem to have fended off any further efforts by the Reagan administration to shift from staffed legal services offices to clinics. A 2015 survey bears this out. It indicates that clinics now play a minimal role in the delivery of legal aid in the USA; law school clinics account for less than $2 \%$ of all clients served (Houseman 2015 , p. 26). For historical reasons, then, it is very unlikely one will see any law school clinic in the USA that provides a significant portion of the legal aid services in any locality. 


\section{Early Legal Clinics in Central Europe: Poland's Clinical Links to Legal Aid}

\section{Post-Soviet Rapid Expansion of Clinics}

Clinical legal education emerged in Europe with a much different trajectory than that of the USA. It began in earnest in Central Europe with the fall of the Soviet Union, which formally dissolved in 1991. The instability and reform impulses of the post-Soviet period created space for innovation within traditional law schools. The first clinic to see real clients in the post-Soviet era of Central Europe came into being at Palacky University in Olomouc, Czech Republic, in 1995, with support from the Ford Foundation. A later review of the clinic notes that it 'stagnated both in number of students and in quality of education,' in part owing to financing difficulties and lack of faculty involvement. With renewed funding from European and national sources, the clinics at Palacky revived and grew to five, as of 2006 (Bryxová et al. 2006, p. 150). The first clinic in Russia began to operate with a full complement of students in February of 1996, as a result of a sister-state relationship begun as early as 1994 between Vermont Law School in the USA and Petrozavodsk State University, in the Karelia region of Russia (May 1997). Throughout the 90 s and first decade of the new century, clinical legal education programmes based in universities grew in number and academic standing. In part, this was due to funding support from international donors, public, and private (Wilson 2004). In addition, the Bologna Process, begun in 1999, provided an impulse for European higher education reform; it also played an important role in creating space for innovations such as legal clinics (Terry 2008).

\section{The Polish Case}

Poland, perhaps uniquely to the region, began on a small scale but then pursued an aggressive path toward the adoption of clinics on a nationwide basis, with much of the emphasis of clinical work focused on access to justice, the social mission of clinics, and legal aid services that the state 
was not providing. The first clinic in Poland was at the Jagiellonian University in Krakow, where a Human Rights Clinic began operating in the fall of 1997 (Rekosh 2008, p. 98). Shortly after its founding, the Human Rights Clinic received an influential grant from the UN High Commissioner on Refugees (UNHCR) to provide representation to asylum seekers and other refugees (Wortham 2006, p. 622). That grant, in turn, gave rise to intense efforts by UNHCR to fund clinical legal education as a means of providing legal aid to refugees in the new accession countries of the European Union. Although relatively short-lived, the collective projects gave rise to at least 23 refugee law clinics in 11 countries in the region, as well as an annual asylum law moot court competition and other on-line resources, all of which were a form of legal assistance to persons in need who would otherwise not have been served by the legal system (Konstantinov 2004, slide 16).

Clinics spread quickly in Poland. After the start of the Jagiellonian clinic, Warsaw University quickly followed in 1998, and Białystok University began a tax clinic in 1997 that later developed into a larger clinical programme. Students enrol in clinics in their fourth and fifth years of study, after three years of theoretical classroom work, making it part of their Masters studies (Skrodzka et al. 2008, pp. 58-59, p. 71). Since their early beginnings, clinics have spread throughout the country, with 25 clinics in 16 cities as of the 2012-2013 academic year (FUPP 2015). Clinics have been established in every public university in the country, and in virtually all of the private universities. As their national reach has grown, their focus has moved to one of provision of legal aid services to the poor.

\section{The Polish Legal Clinics Foundation (FUPP) as Unifying Influence}

A strong influence in the spread of clinics in Poland was the creation, in 2002 , of a national entity with its focus exclusively on clinical legal education, the Polish Legal Clinics Foundation, or FUPP, as it is known by its Polish acronym. FUPP went into operation quite quickly, with the goals of strengthening the structure of clinical education and providing 
a national platform for training, support, and standards in the operations of clinics. FUPP has since become not only a national role-player in legal education but a patron for international relationships of Polish clinics with others on a worldwide basis. Today, every clinic that comes into existence in Poland strives to meet the minimum national standards established by FUPP for all clinics; the organisation plays a role not only in the approval of clinics but also in their financing and relationships with the national government. As a result, almost all of the clinics in Poland are included within the curriculum of study for a law degree, and office costs and professors' salaries are paid by the universities; very few of the costs of clinics are borne by the government (FUPP 2015). Because of its strong relationship with the national ombudsman of Poland, FUPP also plays a key role in the development of laws and regulations on access to legal aid, as well as in the provision of pro bono legal services throughout the nation. It sponsors frequent national clinical conferences and workshops, and has developed a voluminous manual on clinics, now available in English, Russian, and Chinese. The foundation has also published a number of texts on clinical legal education at the national level.

The foundation documents the work performed by clinics throughout Poland. From the data available, it is clear that clinics within the FUPP network see their mission as twofold. First, clinics fill an educational goal of teaching practice skills and ethics to massive numbers of law students who participate in the programmes through work with real clients. Second, clinics fulfil a social goal of providing legal services to poor and otherwise unrepresented people. Statistics show that during 2012-2013, almost 2000 students and some 250 teacher-supervisors participated in clinics. This represents a steady increase in student and faculty participation in the programmes over the life of FUPP. During a nine-month period between 2012 and mid-2013, some 11,100 cases were reviewed in legal clinics, about $30 \%$ of which dealt with civil law matters. Other significant areas of student work include criminal cases, family matters, and labour and unemployment issues (FUPP 2015). One authority estimated, more than a decade ago, in 2003 , that clinics provided about $30 \%$ of all legal aid services at that time, with the rest being provided by lawyers and non-governmental 
legal services organizations (Bojarski 2005, p. 27). Given that the caseload of clinics has more than doubled since that year, it can be assumed that legal clinics may be the most significant providers of legal aid to the poor in the country.

One concern about providing such a large array of services is the potential clash of the pedagogical and social missions of clinics. If too many cases are handled by novice lawyers-to-be, neither the clients nor the students are well-served, and speedy, pro-forma representation can result in real damage to the claims of clients, each of whom brings a unique story. There must be a learning space in which students can acquire both the doctrinal and lawyering skills necessary to provide effective representation in any real legal matter. Polish clinics purport to mitigate these concerns in two ways. First, the strong faculty participation in the programme ensures that student supervision and oversight is close, and caseloads are limited. The average student-to-faculty ratio for supervision purposes is now around seven to one, comparable to most clinics in the USA and much lower than many clinics in the region. Second, legal aid representation is largely limited to non-court matters and advice or referral. Some $86 \%$ of all cases are resolved with one to two visits to the clinic, and within two months. Students are expected to work with at least two clients during an academic year, and most students resolve about six cases per year (Czernicki 2015; FUPP 2015). Efficiency is a goal, but not at the expense of pedagogical soundness.

Poland is unique in many ways with regard to its fast-growing clinical offerings. First, it developed a totally indigenous clinical movement, unique in itself, but drawing from the prior experience of others. Interestingly, it took its model not so much from contemporary US structures but from other strong clinical programmes around the world, particularly that of South Africa, which gave Poland a programme strongly grounded in legal aid work, but also a structural model for its national accrediting agency, the FUPP, drawing on South Africa's Association of University Legal Aid Institutions (AULAI). AULAI plays a strong role in South Africa in the structures and funding of clinics, with an endowment from the Ford Foundation to strengthen clinic funding (McQuoid-Mason 2008, p. 9). In describing the wide variety of clinical programmes in South Africa, McQuoid-Mason draws sharp distinctions 
between what he calls 'state-funded law clinics', and those he calls 'independent law clinics'. The former group of clinics provides legal aid services. However, those clinics also offer a service for students that is unique in the world, at least in my experience. As a result of law changes in 1993, prospective lawyers can complete their required articles of clerkship, or practical training after law school, through legal aid service in a clinic. In return, the government funds those clinics to provide legal aid services. As of 2000, 20 clinics functioned in this way, although government support was quite minimal —no more than $\$ 72,000$ per year for their operations. It is the independent law clinics that receive support from the AULAI Trust (McQuoid-Mason 2000, pp. 123-124, p. 129). Recent scholarship from South Africa has been critical of the role of clinics there in providing only legal aid services, claiming that such clinics dilute a clinic's purely pedagogical mission. A recent article collects critiques of the legal aid clinic model from Australia, UK, the USA, and India, as well as from South Africa itself (DuPlessis and Dass 2013, pp. 397-400). McQuoid-Mason himself puts the matter quite succinctly:

The greatest challenge for general practice [legal aid] clinics is how to limit the numbers of clients so that the clinics do not become overwhelmed. If the number of clients exceeds the capacity of the clinic both the clients and the clinic will suffer. The clients will suffer because they will not receive proper advice and service. The clinic will suffer because its reputation will be harmed and its staff and students demoralized. Intakes need to be limited and clients referred to other agencies once the clinic reaches its capacity. (McQuoidMason 2008, p. 6)

A second strength of the Polish clinic system is that it is the only country in the Central and East European region to provide a significant portion of the nation's legal aid services through clinics, although students themselves never appear in court. However, legal aid is not the only mission of clinics, as is evidenced by the early clinics that provided legal services in human rights and other areas. A third unique aspect is that, while many other countries from the former Soviet bloc have nationwide clinical education associations, none has the certifying powers of the Polish FUPP. Poland is not unique in its struggle to provide legal aid systematically, a challenge for all of Europe and the world. Major reform appears 
to be on the horizon. Poland is about to adopt a comprehensive new programme of staffed legal aid offices in 2016, which may affect the reach and involvement of clinics in such services (Czernicki 2015).

\section{The Aftermath: Let a Hundred Flowers Bloom Throughout Europe and the USA}

Recent developments in Western Continental Europe and the USA indicate that clinics are thriving and growing apace. In the USA, virtually every one of the nation's 198 accredited law schools has more than one clinic: a national survey for 2013-2014 indicates that the average number of different subject-matter clinics at each school is seven, with nearly a quarter of the clinics working in the areas of criminal defence, immigration, children and the law, and mediation, or other alternative dispute resolution methods. An average of from 51\% to 55\% of all law students in the USA participate in a clinic, with a median enrolment in individual clinics of from nine to twelve students. Faculty supervision in clinics is also gaining greater stability. In the relevant time period, nearly $44 \%$ of all clinic faculty were either tenured or tenure-track employees. Another $75 \%$ of all faculty employees are on presumptively renewable full-time contracts. Student-teacher ratios are generally stable at between 6 to 1 , and 8 to 1 , in order to assure adequate supervision. Virtually all clinics receive academic credit for both fieldwork and seminar components, although the average clinic experience is only one semester of the six semesters of legal study, and is generally part of a larger class load for fulltime students.

There is no hard data today giving estimates of the sources of funding for US law school clinics. Very little comes from state or federal sources. The last such data I have found comes from a report by the American Bar Association for the years 1991-1992. According to that report, $68.4 \%$ of funding, the majority came from the law school or university budget (hard money). Another 12\% came from state sources that no longer contribute today: federal grants under Title IX, which formerly provided seed money grants for clinics, and the LSC, discussed above. Another 8\% came from foundation grants, with only $3.8 \%$ coming from other state 
agency funding. A small remaining percentage of funding came from lawyers' fees and earmarked alumni donations (American Bar Association 1992, p. 250). The more recent national survey of clinical legal education only suggests budgetary issues by identifying the lack of hard money (money within the law school's own budget) as the most significant challenge facing in-house clinics (Kuehn and Santacroce 2015, p. 14). Given the number of law schools and clinics, it should not be surprising that the survey estimates that clinics gave over 3.4 million hours of pro bono civil legal services during the 2012-2013 academic year, or just over 3300 hours per clinic. Clinics are estimated to have provided free civil legal services to over 70,000 individuals during that year (Kuehn and Santacroce 2015). Thus, although clinics in the USA are not generally linked to legal aid programmes, their contribution to civil justice in the USA is significant.

Six years ago, I wrote an article arguing that continental Western Europe was what I called 'the last holdout' in accepting clinical legal education. I argued that there were many possible explanations for that phenomenon, noting that clinics have thrived in the USA and the rest of the common law world, and they are a commonplace throughout Latin America, Asia, and Central and Eastern Europe. I then counted less than 10 clinics in all of continental Western Europe (Wilson 2009). Again, in 2012, after acquiring new comparative data, I concluded that 'clinical legal education is conspicuous by its absence in Western European countries.' (Wilson 2012, p. 71) Now, only four years later, I believe that my conclusions no longer hold true. Based on some rapidly evolving data on the ground, and on some empirical data, I believe Western Europe is joining the international chorus singing the virtues of clinical legal education as part of the law school curriculum. Although many of the clinics did not begin operations until after 2011, one survey identifies 51 clinics in Western Europe, in the following countries: Austria, Belgium, France, Germany (which has 24, the most), Italy, the Netherlands, Norway, and Spain. There may well be more that have not yet been documented. Europe now also has its own regional clinical organisation, the European Network for Clinical Legal Education, or ENCLE, with a rapidly growing list of participating institutions across the continent. 
While no systematic information is available as to the nature of the work performed by these clinics, or the sources of their funding, my strong impression is that, in general, European clinics have not been organised on the Polish model, primarily as a means to provide legal services to the poor. In fact, most of the countries in question have robust legal aid programmes provided by the private bar or NGO groups. One notable exception is the Juss-Buss programme in Oslo (see Chap. 2 above), and a very impressive programme in action, as I can attest from a personal visit to its operations in 2012. Otherwise, the range of clinical offerings is quite diverse: asylum and immigration, business law, environmental law, international human rights, or multiple subject matters, to name but a few. This broad range of offerings reflects a general sense that clinic content is governed by local conditions, and such local conditions often include the interests and abilities of the teachers and students involved in the clinic, as well as the general local legal culture, both inside and outside of the university. Clinics can provide valuable legal services to the poor in civil matters but great caution should be taken, as has been the case in Poland, to ensure that there is adequate supervision of student work-product, as well as appropriate limited caseloads per student over the time of enrolment, in order to provide maximum pedagogical opportunities while providing much-needed legal services to the community.

\section{References}

Abel, R. L. (1985). Law without politics: Legal aid under advanced capitalism. UCLA Law Review, 32, 474.

American Bar Association. (1992). Legal education and professional development: An educational continuum. Report of the task force on law schools and the profession: Narrowing the gap.

Barry, M., Dubin, J., \& Joy, P. (2000). Clinical education for this millennium: The third wave. Clinical Law Review, 7, 1.

Bennett, M., \& Reynoso, C. (1972). California rural legal assistance (CRLA): Survival of a poverty law practice. Chicano Law Review, $1,1$.

Bloch, F. S., \& Noone, M. A. (2011). Legal aid origins of clinical legal education. In F. S. Bloch (Ed.), The global clinical movement: Educating lawyers for social justice. New York/Oxford: Oxford University Press. 
Bojarski, Ł. (2005). The social aspect of legal clinics. In The legal clinic: The idea, organization, methodology (pp. 19-26). Warsaw: The Legal Clinics Foundation.

Bradway, J. S. (1933). Legal aid clinics: Their purpose and their value to the bar. The [California] State Bar Journal, 8, 261-264. California.

Bryant, S., Milstein, E. S., \& Shalleck, A. C. (2014). Transforming the education of lawyers: The theory and practice of clinical pedagogy. Durham: Carolina Academic Press.

Bryxová, V., et al. (2006). Introducing legal clinics in Olomouc, Czech Republic. International Journal of Clinical Legal Education, 9, 149-150.

Capowski, J. J. (1984). Legal services corporation grants for clinical education. In Association of American Law Schools section on Clinical Legal Education. Newsletter, March 1984.

Committee on Legal Services. (1987). In AALS section on Clinical Legal Education. Newsletter, 4 November.

Czernicki, F. (2015, October 21-22). President of the polish legal clinics foundation (email exchange with the author).

Davis, M. F. (1995). Brutal need: Lawyers and the welfare rights movement. 1960-1973. New Haven: Yale University Press.

DuPlessis, M. A., \& Dass, D. (2013). Defining the role of the university law clinician. South African Law Journal, 130, 390.

FUPP. (2015). Legal clinics in Poland: 2003-2013. PowerPoint available at http://www.fupp.org.pl/en/. Visited on 22 October 2015.

Gideon v. Wainwright. (1963). 372 U.S. 335.

Houseman, A. W. (2015, May 14). Civil legal aid in the United States: An update for 2015. Washington: Center for Law and Social Policy (CLASP).

Houseman, A. W., \& Perle, L. E. (2013). Securing equal justice for all: A brief history of civil legal assistance in the United States. Washington: Center for Law and Social Policy (CLASP).

Kuehn, R. R., \& Santacroce, D. A. (2015). Survey of applied legal education. 2013-14. Center for the Study of Applied Legal Education, University of Michigan.

Konstantinov, B. (2004, June 5-6). Developing refugee law clinics in Europe's transitioning countries (PowerPoint presentation).

Lawrence, S. E. (1990). The poor in court: The legal services program and supreme court decision making. Princeton: Princeton University Press.

LSC Announces Grants. (1984). In AALS section on Clinical Legal Education. Newsletter, 7 June 7. 
LSC Announces New Clinical Program. (1983). In AALS section on Clinical Legal Education. Newsletter, 4 November.

May, J. C. (1997). Creating Russia’s first law school legal clinic. The Vermont Bar Journal \& Law Digest, 23, 43.

McQuoid-Mason, D. (2000). Essay on the delivery of legal aid services in South Africa. Fordham International Law Journal, 24, 111.

McQuoid-Mason, D. (2008). Law clinics at African universities: An overview of the service delivery component with passing references to experiences in South and South-East Asia. Journal for Juridical Science, (Special Issue 1).

Milstein, E. S. (2001). Clinical legal education in the United States: In-house clinics, externships, and simulations. Journal of Legal Education, 51, 375.

Moses, C. T. (1990). The law school clinic program. In D. J. Besharov (Ed.), Legal services for the poor: Time for reform (p. 168). Washington, DC: American Enterprise Institute.

Mounts, S. E., \& Wilson, R. J. (1986). Systems for providing indigent defense: An introduction. New York University Review of Law \& Social Change, 14, 193.

Rekosh, E. (2008). Constructing public interest law: Transnational collaboration and exchange in central and Eastern Europe. UCLA Journal for International Law \& Foreign Affairs, 55, 80-82.

Rhudy, R. J. (1994). Comparing legal services to the poor in the United States with other western countries. Maryland Journal of Contemporary Legal Issues, 5, 223-246.

Schrag, P. G., \& Meltsner, M. (1998). Reflections on clinical legal education. Boston: Northeastern University Press.

Skrodzka, M., Chia, J., \& Bruce-Jones, E. (2008). The next step forwardThe development of clinical legal education in Poland through a clinical pilot program in Białystok. Columbia Journal of East European Law, 2(1), 56-93.

Smith, R. H. (1919). Justice and the poor. New York: Arno Press.

Smith, R. H., \& Bradway, J. S. (1936). Growth of legal aid work in the United States. US Department of Labor, Bureau of Labor Statistics.

Stuckey, R. (2005, October 7). The history of the KBG and the Gang of Eight (1979-1993) (Draft, on file with the author).

Terry, L. S. (2008). The bologna process and its impact in Europe: It's so much more than degree changes. Vanderbilt Journal of Transnational Law, 41(107), $113-114$. 
United States General Accounting Office. (1978). Free legal services for the poorIncreased coordination, community legal education, and outreach needed. Report to the Congress by the Comptroller General of the United States.

von Briesen, A. (1907). The Copenhagen legal aid society. Legal Aid Review, 5, 25.

Wilson, R. J. (2004). Training for justice: The global reach of clinical legal education. Penn State International Law Review, 22, 421.

Wilson, R. J. (2009). Western Europe: Last holdout in the worldwide acceptance of clinical legal education. German Law Review, 10, 823.

Wilson, R. J. (2012). The role of practice in legal education. InGeneral reports of the XVIIIth congress of the international academy of comparative law (p. 57).

Wortham, L. (2006). Aiding clinical education abroad: What can be gained and the learning curve on how to do so effectively. Clinical Law Review, 12, 615.

Open Access This chapter is distributed under the terms of the Creative Commons Attribution 4.0 International License (http://creativecommons.org/ licenses/by/4.0/), which permits use, duplication, adaptation, distribution, and reproduction in any medium or format, as long as you give appropriate credit to the original author(s) and the source, a link is provided to the Creative Commons license, and any changes made are indicated.

The images or other third party material in this book are included in the work's Creative Commons license, unless indicated otherwise in the credit line; if such material is not included in the work's Creative Commons license and the respective action is not permitted by statutory regulation, users will need to obtain permission from the license holder to duplicate, adapt or reproduce the material.

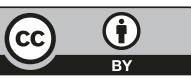

